\title{
The Open Business Model: Understanding an Emerging Concept
}

\author{
Tobias Weiblen \\ University of St. Gallen, Institute of Technology Management, Switzerland
}

Received 12 March 2014 Accepted 26 May 2014

Publication: 28 July 2014

\begin{abstract}
Along with the emergence of phenomena such as value co-creation, firm networks, and open innovation, open business models have achieved growing attention in research. Scholars from different fields use the open business model, largely without providing a definition. This has led to an overall lack of clarity of the concept itself. Based on a comprehensive review of scholarly literature in the field, commonalities and differences in the perceived nature of the open business model are carved out. Consulting additional literature and cases on open innovation and business models, the tensions found are resolved, putting a special focus on the relationships between open business models, open innovation, and business models in general. The resulting definition and conceptual framework structure the three fields and provide a set of differentiation criteria that should lead to a more consistent and deliberate use of the open business model concept in the future.
\end{abstract}

Keywords: Open business model, Open innovation, Business model, Inter-firm Collaboration, Openness.

\section{Introduction}

Since Chesbrough's (2006a) seminal book on the topic, the "open business model" has become a frequently used term in literature. It filled a gap in management research by linking the open innovation phenomenon

Journal of Multi Business Model Innovation and Technology, Vol. 1, 35-66.

doi: 10.13052/jmbmit2245-456X.212

(c) 2014 River Publishers. All rights reserved. 
(Chesbrough, 2003) to the increasingly popular business model concept (Zott, Amit, \& Massa, 2011). Combining a young and vibrant field of innovation research with an emerging concept that itself lacks a clear definition (cp. George \& Bock, 2011; Morris, Schindehutte, \& Allen, 2005; Shafer, Smith, \& Linder, 2005), however, came at a price. To date, perceptions of what the open business model actually is differ considerably among scholars. Neither is the concept clearly defined, nor is it clearly delineated from the closely related business model and open innovation fields. One might even pose the heretical question whether the open business model is of any theoretical or practical value at all, given that it is so hard to distinguish.

Within a research domain, a common language based on clarity of terms and concepts is an important prerequisite for cross-fertilization and the development of complementary knowledge. This paper hence tries to contribute to the understanding of the open business model by providing a comprehensive overview of the literature dealing with the concept. Based on a review of 24 scholarly articles, commonalities and diverging perceptions are outlined and reflected against the state of research in the business model and open innovation fields. Assuming a static view of the business model, this extended theoretical background serves as the basis to develop an argument which defines and locates the open business model conceptually. The achieved clarification of the relationships between open innovation, business model, and open business model concepts is sharpened by incorporating real-world cases from the extant literature in the three fields. The resulting framework, along with differentiation criteria separating the concepts, leads to a clearer picture of the open business model itself and of its practical relevance. The contribution hence lies in structuring the field of research and in preventing its premature divergence and fragmentation, laying the grounds for future research on the open business model. The paper concludes identifying future directions into which open business model research could develop to strengthen the field's profile as an emerging and relevant part of business model research.

\section{Method}

The literature review focuses on the understanding of the open business model in literature by synthesizing how different authors use the concept and how they delineate it from related fields. Based on the recommendations of vom Brocke et al. (2009) and Webster \& Watson (2002), a systematic literature search approach is used and detailed record thereof is provided (see Appendix for additional details). The initial search was conducted with 
the search string "open business model*" in title, abstract, or key words of scholarly (i.e., peer reviewed) journals. Possible alternative search terms, such as "collaborative business model" or "networked business model", were excluded purposefully since the open business model's perception was the subject of interest in the first place ${ }^{1}$. To find matching articles the EBSCOhost Discovery Service meta search was employed. It compiles its results from a broad set of scholarly databases such as JSTOR, SSCI, and ScienceDirect. All available catalogs were queried, including the comprehensive Business Source Complete database used, for instance, in (Zott, Amit, \& Massa, 2011). The resulting set of 35 articles was reduced manually by sorting out obvious duplicates, non-English articles, non-scholarly articles, and book reviews (Search A).

Due to the low number of 18 remaining hits, of which some hardly elaborated on the open business model despite its mentioning in abstract or key words, it was decided to conduct a second search on a broader basis. For this, the Google Scholar search engine (excluding patents and citations) with an unrestricted search on the same search string was employed, screening the displayed excerpts of all 515 hits (Search B). This second search allowed to also consider relevant forthcoming journal articles, conference proceedings, and book chapters not covered by Search A. Six papers from the search B set were selected based on the fit of their abstracts with the research interest, i.e. the papers had to promise insightful research on the open business model as a concept and preferably on its relation to open innovation and business models in general.

The final set of 24 papers (see Appendix for an overview) was read and understood in detail, with a particular focus on the authors' use and understanding of the open business model concept. More precisely, answers to the following questions were sought:

- How do the authors define (or at least use) the term "open business model"?

- How do they delineate the concept from the "open innovation" and "business model" domains?

- Which common themes emerge and which concepts are seen as related?

\footnotetext{
${ }^{1} \mathrm{NB}$ : The term "open business model" has the highest usage in scientific literature according to Google Scholar search. In January 2014, the term's 728 hits are more than the sum of "collaborative business model" (480 hits) and "networked business model" (160 hits). Given the open business model's unclear definition and nature, it seems appropriate to exclusively focus this paper on the clarification of this single concept. Exploring commonalities and differences with similar business model types marks an interesting route for future research.
} 
The next section provides a detailed overview of the answers found - and not found - in the reviewed literature.

\section{The Open Business Model in Literature}

\subsection{Emergence}

As Figure 1 illustrates, the open business model has seen a strong increase in scholarly attention over the past years. Judging from the comparably low number of hits in Search A (peer-reviewed scholarly journals), however, it seems legitimate to conclude that the concept has not yet made its way into the world of top-class research. As per the author's impression, most contributions on the topic stay within the levels of conference- or working papers. Apart from the open business model's newness as a concept, its lack of definition and clarity as outlined below might be a reason for this second-class status.

Most of the reviewed papers locate the origin of the open business model concept in Chesbrough (2006a). Historically, earlier occurrences of the term can be spotted in the context of telecommunication networks. Without providing a definition, scholars in this field use it to describe network architectures which allow new network peers to join (Dijkstra et al., 2005) or new players to offer their contents and services on top of a network (Bougant, Delmond, \& Pageot-Millet, 2003; Pereira, 2001). Chesbrough (2006a, 2007) deserves the

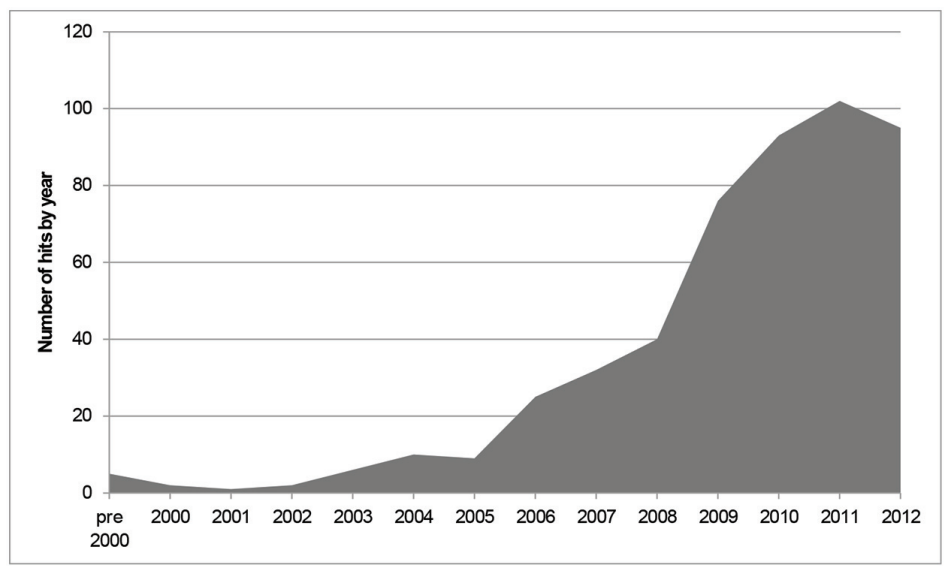

Figure 1 Publications containing the term "open business model" by year, according to Google Scholar search (Search B) 
credit for bringing the open business model to management scholars' attention and for stimulating research in the field. Given the high number of citations of his work, a large portion of the visible post-2006 increase in Figure 1 can be assumed to go back to his seminal book.

With respect to the research designs employed, the reviewed set of papers shows a clear tendency towards conceptual (13 papers) and qualitative empirical (9 papers) approaches (see Appendix for a detailed per-paper overview). Only two papers in the set are of quantitative empirical nature (Alexy \& George, 2011; Cheng, 2011). This distribution might hint at the open business model's newness as a concept in research.

\subsection{Definition and Meaning}

Since the vast majority of the reviewed papers are in line with Chesbrough (2006a) in not providing a clear definition of the concept, approaching the term "open business model" from the words' semantics seems advisable. The term can be split into two components: an adjective - "open" - describing the noun "business model". It is interesting to see that, in the sample of 24 core articles, authors share a more common understanding of the term "open" than of the term "business model". Open is generally seen as referring to a firm's boundaries and its collaboration with the outside world across these boundaries - be it with other firms, communities, or customers ${ }^{2}$. With regards to the business model, a variety of conceptions becomes obvious. Authors see it as description of generic roles in a network (Vetter, Fredricx, Rajan, \& Oberle, 2008), as a collaboration model (Luo \& Chang, 2011), the principles of core repeated processes (Smith, Cavalcante, Kesting, \& Ulhøi, 2010), a mediating construct between technology innovation and economic value (Wang, Jaring, \& Arto, 2009), or a set of building blocks (Chanal \& Caron-Fasan, 2010; Holm, Günzel, \& Ulhøi, 2013). Most authors, however, resort to or include the least common denominator in business model research, which is that a business model describes the logic of value creation and value capturing of a firm (Teece, 2010; Zott et al., 2011). The definition provided by Teece (2010, p. 191) is used for this study: "A business model describes the design or architecture of the value creation, delivery and capture mechanisms employed [by a particular business]."

So, in combination of the terms, does the open business model describe "doing business" across firm boundaries or is there a special meaning

\footnotetext{
${ }^{2}$ A noteworthy exception here are Soloviev, Kurochkin, Rendiuk, \& Zazuk (2010), who explicitly equate "open" and "free" (in its free-of-charge meaning).
} 
behind it? Given the aforementioned diverging perceptions and the ongoing debate as to what a business model actually is (George \& Bock, 2011; Zott et al., 2011), a common understanding of the open business model across the set of articles is not to be expected. Definitions and perceptions of the open business model can, however, be clustered into two broad streams: the open innovation view and the business model view. In the following sections, both views are presented separately.

\subsubsection{Open innovation view of the open business model}

In Chesbrough's view, the open business model is closely related to the open innovation concept (Chesbrough, 2006a). Open innovation is defined as "the use of purposive inflows and outflows of knowledge to accelerate internal innovation and to expand the markets for external use of innovation, respectively" (Chesbrough, 2006b, p.1). It is a generic term that captures recent phenomena such as IP commercialization, user and customer integration, and collaborative R\&D processes (Gassmann, Enkel, \& Chesbrough, 2010). Not providing a comparably concise definition of the open business model, Chesbrough (2006a, p.107) argues that "companies must develop open business models if they are to make the most of the opportunities offered by open innovation". "To get the most out of this new system of innovation, companies must open their business models by actively searching for and exploiting outside ideas and by allowing unused internal technologies to flow to the outside, where other firms can unlock their latent economic potential" (Chesbrough, 2007, p. 22). With his focus on technology, innovation, and ideas, Chesbrough clearly ties the open business model to openness with regards to a firm's research and development (R\&D) activities. In this view of the concept, an open business model is always accompanied by open innovation principles successfully implemented in a firm's R\&D.

The R\&D-centric perception of the open business model reflects in the overall themes of the papers assuming this open innovation view (cp. Table 1). All of the 13 papers that fall into the category directly reference Chesbrough (2006a) to explain the open business model. Table 1 gives an overview of the different flavors that the authors give to their perceptions of the concept (in case no quotable perception is provided in the source, its essence is summarized by the author).

Despite the common grounding of the concept in open innovation, some confusion concerning the relation between open innovation and open business models can be observed. As the last column of Table 1 illustrates, the set of articles falls into three groups: 
Table 1 Papers following the open innovation (OI) view of the open business model (OBM)

\begin{tabular}{|c|c|c|c|}
\hline Paper & Theme & OBM Perception & $\begin{array}{l}\text { OBM/OI } \\
\text { Relation }\end{array}$ \\
\hline (Luo \& & By utilizing open & "The OBM transforms & Same \\
\hline Chang, 2011) & $\begin{array}{l}\text { business models that lead } \\
\text { to the division of labor, } \\
\text { SMEs in Taiwan's } \\
\text { original device } \\
\text { manufacturer industry can } \\
\text { share R\&D costs and stay } \\
\text { profitable despite global } \\
\text { competitive pressure. }\end{array}$ & $\begin{array}{l}\text { innovation and technology } \\
\text { into economic results. Using } \\
\text { a combination of innovative } \\
\text { strategies and continuously } \\
\text { integrating internal and } \\
\text { external resources, the OBM } \\
\text { promotes corporate } \\
\text { competitiveness, establishes a } \\
\text { network of collaboration } \\
\text { relationships, and forms } \\
\text { intercommunication platform } \\
\text { models [...]" }\end{array}$ & $\begin{array}{l}\text { (OI not } \\
\text { mentioned) }\end{array}$ \\
\hline $\begin{array}{l}\text { (Chesbrough } \\
\text { \& Schwartz, } \\
\text { 2007) }\end{array}$ & $\begin{array}{l}\text { Co-development } \\
\text { partnerships improve } \\
\text { innovation effectiveness. } \\
\text { To achieve such open } \\
\text { business models, the } \\
\text { various R\&D activities } \\
\text { need to be categorized } \\
\text { and the business models } \\
\text { of both partners aligned. }\end{array}$ & $\begin{array}{l}\text { Open business models are a } \\
\text { prerequisite for successful } \\
\text { co-development partnerships. }\end{array}$ & $\begin{array}{l}\mathrm{OBM}=\mathrm{BM} \\
\text { adjusted to OI }\end{array}$ \\
\hline $\begin{array}{l}\text { (Chu \& Chen, } \\
\text { 2011) }\end{array}$ & $\begin{array}{l}\text { Increased complexity of } \\
\text { system-on-chip R\&D } \\
\text { leads to the emergence of } \\
\text { a new intermediary: the } \\
\text { design foundry. Its open } \\
\text { business model is } \\
\text { analyzed. }\end{array}$ & $\begin{array}{l}\text { "As an extension of open } \\
\text { innovation, open business } \\
\text { models underscore a concept } \\
\text { of industry ecosystem." }\end{array}$ & $\begin{array}{l}\mathrm{OBM}=\mathrm{BM} \\
\text { based on } \mathrm{OI}\end{array}$ \\
\hline $\begin{array}{l}\text { (Davey, } \\
\text { Brennan, } \\
\text { Meenan, \& } \\
\text { McAdam, } \\
\text { 2010, 2011) }\end{array}$ & $\begin{array}{l}\text { Incorporating input of } \\
\text { external stakeholders } \\
\text { (engineers, clinicians, } \\
\text { patients) into R\&D } \\
\text { allows medical devices } \\
\text { manufacturers to innovate } \\
\text { more effectively. }\end{array}$ & $\begin{array}{l}\text { "A successful open business } \\
\text { model creates heuristic logic } \\
\text { that connects technical } \\
\text { potential with the realization } \\
\text { of economic value." }\end{array}$ & $\begin{array}{l}\text { Same } \\
\text { (OBM also called } \\
\text { "open innovation } \\
\text { business model") }\end{array}$ \\
\hline $\begin{array}{l}\text { (Chesbrough, } \\
\text { 2007) }\end{array}$ & $\begin{array}{l}\text { Innovation effectiveness } \\
\text { can be improved by } \\
\text { migrating from closed to } \\
\text { open business models. }\end{array}$ & $\begin{array}{l}\text { "Open business models } \\
\text { enable an organization to be } \\
\text { more effective in creating as } \\
\text { well as }\end{array}$ & $\begin{array}{l}\mathrm{OBM}=\mathrm{BM} \\
\text { adjusted to OI }\end{array}$ \\
\hline
\end{tabular}


42 T. Weiblen

Table 1 Continued

\begin{tabular}{|c|c|c|c|}
\hline Paper & Theme & OBM Perception & $\begin{array}{l}\text { OBM/OI } \\
\text { Relation }\end{array}$ \\
\hline & & $\begin{array}{l}\text { capturing value. They help } \\
\text { create value by leveraging } \\
\text { many more ideas because of } \\
\text { their inclusion of a variety of } \\
\text { external concepts. They also } \\
\text { allow greater value capture by } \\
\text { utilizing a firm's key asset, } \\
\text { resource or position not only } \\
\text { in that organization's own } \\
\text { operations but also in other } \\
\text { companies' businesses." }\end{array}$ & \\
\hline $\begin{array}{l}\text { (Chanal \& } \\
\text { Caron-Fasan, } \\
\text { 2010) }\end{array}$ & $\begin{array}{l}\text { Web platforms around } \\
\text { idea communities can } \\
\text { lead to tensions around IP } \\
\text { ownership, usage, and } \\
\text { incentives. Adjusting the } \\
\text { business model of such } \\
\text { platforms is an ongoing } \\
\text { process. }\end{array}$ & $\begin{array}{l}\text { Open business models can } \\
\text { include external communities } \\
\text { as valuable resources. }\end{array}$ & Same \\
\hline $\begin{array}{l}\text { (Y. Wang \& } \\
\text { Zhou, 2012) }\end{array}$ & $\begin{array}{l}\text { The appropriateness of } \\
\text { the open innovation } \\
\text { approach for latecomer } \\
\text { firms in emerging } \\
\text { countries is analyzed and } \\
\text { found to be inappropriate. }\end{array}$ & $\begin{array}{l}\text { "[...] open innovation } \\
\text { players select a proper } \\
\text { business model to unlock the } \\
\text { value of technology, which } \\
\text { could be called as the } \\
\text { open-innovation-based } \\
\text { business model." }\end{array}$ & Same \\
\hline $\begin{array}{l}\text { (Soloviev, } \\
\text { Kurochkin, } \\
\text { Rendiuk, \& } \\
\text { Zazuk, 2010) }\end{array}$ & $\begin{array}{l}\text { New open business } \\
\text { models give away } \\
\text { products for free, the } \\
\text { challenge is to make } \\
\text { profit. Different options } \\
\text { can be the right choice } \\
\text { depending on the context. }\end{array}$ & $\begin{array}{l}\text { "The main advantage of the } \\
\text { open business model is that } \\
\text { this model involves the value } \\
\text { creation by the efforts of a } \\
\text { large community of } \\
\text { developers." }\end{array}$ & $\begin{array}{l}\text { Same } \\
\text { (OI not } \\
\text { mentioned) }\end{array}$ \\
\hline $\begin{array}{l}\text { (Gassmann, } \\
\text { Enkel, et al., } \\
\text { 2010) }\end{array}$ & $\begin{array}{l}\text { Open innovation has } \\
\text { developed into its own } \\
\text { field of research. } \\
\text { Different perspectives } \\
\text { shed more light on the } \\
\text { phenomenon. }\end{array}$ & $\begin{array}{l}\text { none (only mentioned in } \\
\text { abstract) }\end{array}$ & Same \\
\hline
\end{tabular}


Table 1 Continued

\begin{tabular}{|c|c|c|c|}
\hline Paper & Theme & OBM Perception & $\begin{array}{l}\text { OBM/OI } \\
\text { Relation }\end{array}$ \\
\hline $\begin{array}{l}\text { (Wang et al., } \\
\text { 2009) }\end{array}$ & $\begin{array}{l}\text { The role of the business } \\
\text { model and of business } \\
\text { model innovation in an } \\
\text { open innovation context } \\
\text { is analyzed. }\end{array}$ & $\begin{array}{l}\text { "The so called 'open } \\
\text { business model' is } \\
\text { different from the current } \\
\text { business model a } \\
\text { company has constructed } \\
\text { and allows internal and } \\
\text { external knowledge to } \\
\text { penetrate in the } \\
\text { operations of companies." }\end{array}$ & $\begin{array}{l}\mathrm{OBM}=\mathrm{BM} \\
\text { adjusted to } \mathrm{OI}\end{array}$ \\
\hline $\begin{array}{l}\text { (Alexy \& } \\
\text { George, } \\
2011 \text { ) }\end{array}$ & $\begin{array}{l}\text { The effects on firm } \\
\text { market value that the } \\
\text { announcement of open } \\
\text { source activities has are } \\
\text { analyzed. Among others, } \\
\text { they depend on the } \\
\text { engagement model. }\end{array}$ & $\begin{array}{l}\text { "The structures and } \\
\text { mechanisms by which } \\
\text { firms access knowledge } \\
\text { outside their } \\
\text { organizational boundaries } \\
\text { to create value for the } \\
\text { firm, sometimes by } \\
\text { ceding control of product } \\
\text { development pathways } \\
\text { and its own intellectual } \\
\text { property rights, are } \\
\text { referred to as 'open } \\
\text { business models'." }\end{array}$ & $\begin{array}{l}\mathrm{OBM}=\mathrm{BM} \\
\text { based on OI } \\
(\mathrm{OBM} \text { also } \\
\text { called 'open } \\
\text { and } \\
\text { distributed } \\
\text { innovation } \\
\text { business } \\
\text { model') }\end{array}$ \\
\hline $\begin{array}{l}\text { (Smith et al., } \\
\text { 2010) }\end{array}$ & $\begin{array}{l}\text { Open innovation occurs } \\
\text { on an operational level. It } \\
\text { is only successful, if - on } \\
\text { a more strategic level - } \\
\text { the business model is } \\
\text { adjusted accordingly. } \\
\text { This adjustment process } \\
\text { is analyzed. }\end{array}$ & $\begin{array}{l}\text { "The business model } \\
\text { plays a central role in the } \\
\text { open-innovation } \\
\text { paradigm, some authors } \\
\text { argue that firms are more } \\
\text { innovative when they } \\
\text { adopt open business } \\
\text { models." }\end{array}$ & $\begin{array}{l}\mathrm{OBM}=\mathrm{BM} \\
\text { adjusted to } \mathrm{OI}\end{array}$ \\
\hline
\end{tabular}

- Same: for seven of the papers, it was not possible to spot a notable difference between open innovation and open business model. The concepts are used almost synonymously.

- $O B M=B M$ based on OI: in two of the papers, the authors see a firm using open innovation principles as one that implements an open business model but the differentiation is made.

- $O B M=B M$ adjusted to $O I$ : four papers adopt a slightly different standpoint. Here, certain adjustments to the firm's business model have to be made to accommodate for the incorporation of open innovation into R\&D. 
As the last two groups show, there is a slight difference in meaning, but the border between open innovation and the open business model concept is hard to draw. Before taking up this point in the discussion of the results, the remaining papers of the literature base, which take a broader perspective on the open business model, are presented.

\subsubsection{Business model view of the open business model}

A set of eleven papers takes a broader view on the open business model. Although frequently referencing Chesbrough (six of the papers), the authors do not follow his original perception that an open business model is built around openness in the R\&D activities of a firm. Table 2 provides an overview of these papers, along with their perception of the open business model and the firm activities that they characterize as being open in their studies' contexts.

As becomes obvious from Table 2, the authors assuming the business model view of open business models see basically all firm activities as potential candidates for collaboration and thus openness. While some authors seem unaware of the open innovation view, others, such as Holm et al. (2013), explicitly state their differing perception. A quote from (Sandulli \& Chesbrough, 2009b, p.20) nicely illustrates the move away from just ideas and technologies that cross R\&D boundaries to generic resources that are shared in many areas: "In the past, those few firms with open business models were usually open in a specific function of their business model such as product development, internationalization or distribution, while the rest of the business model remained close. Today, firms are in the process of redesigning all the aspects of their business models under the new open prism."

\subsection{Commonalities between Both Views}

To conclude the review of open business model literature and to take a first step towards reconciling both views, it makes sense to carve out the commonalities between them. The literature base was analyzed for related concepts mentioned, the units of analysis chosen, the attention given to business model innovation, and further common themes.

\subsubsection{Concepts related to open business models}

The concepts that multiple authors refer to in connection with open business models contribute to the understanding of the open business model itself. Apart from typical open innovation themes such as open source (mentioned by eight papers), co-development/crowdsourcing (six papers), or innovation systems (five papers), a number of further concepts are present in both views of the open business model. 
The Open Business Model: Understanding an Emerging Concept

Table 2 Papers following the business model view of the open business model (OBM)

\begin{tabular}{|c|c|c|c|}
\hline Paper & Theme & OBM Perception & $\begin{array}{l}\text { Open } \\
\text { Activities }\end{array}$ \\
\hline $\begin{array}{l}\text { (Romero \& } \\
\text { Molina, } \\
\text { 2011) }\end{array}$ & $\begin{array}{l}\text { Value creation is more and more } \\
\text { performed in collaborative firm } \\
\text { networks and can include } \\
\text { customer communities. A } \\
\text { framework to analyze these } \\
\text { networks is developed. }\end{array}$ & $\begin{array}{l}\text { Seen as equivalent to a } \\
\text { "collaborative business } \\
\text { model" in value networks } \\
\text { and value co-creation } \\
\text { with customers. }\end{array}$ & $\begin{array}{l}\text { All value } \\
\text { creation } \\
\text { activities } \\
\text { (not } \\
\text { detailed) }\end{array}$ \\
\hline $\begin{array}{l}\text { (Vetter et } \\
\text { al., 2008) }\end{array}$ & $\begin{array}{l}\text { Broadband networks can be } \\
\text { used for a multitude of services. } \\
\text { Different players jointly utilize } \\
\text { the infrastructure; different } \\
\text { role-based scenarios are } \\
\text { presented as (open) "business } \\
\text { models". }\end{array}$ & $\begin{array}{l}\text { Open business models are } \\
\text { roles that emerge around } \\
\text { a shared technical } \\
\text { infrastructure. }\end{array}$ & $\begin{array}{l}\text { Network } \\
\text { operations } \\
\text { and content } \\
\text { delivery }\end{array}$ \\
\hline $\begin{array}{l}\text { (Kakaletris, } \\
\text { Varoutas, } \\
\text { Katsianis, } \\
\text { Sphicopou- } \\
\text { los, \& } \\
\text { Kouvas, } \\
\text { 2004) }\end{array}$ & $\begin{array}{l}\text { Tourism-related location-based } \\
\text { services are becoming viable on } \\
\text { mobile devices. An open } \\
\text { business model is required to } \\
\text { integrate content providers into } \\
\text { such joint offerings. }\end{array}$ & $\begin{array}{l}\text { An open business model } \\
\text { integrates different } \\
\text { providers into a joint } \\
\text { service offering. }\end{array}$ & $\begin{array}{l}\text { Mobile } \\
\text { service pro- } \\
\text { visioning, } \\
\text { sale, and } \\
\text { delivery }\end{array}$ \\
\hline $\begin{array}{l}\text { (Jagoda, } \\
\text { Mahesh- } \\
\text { wari, \& } \\
\text { Gutowski, } \\
\text { 2012) }\end{array}$ & $\begin{array}{l}\text { A small real-estate business is } \\
\text { analyzed that successfully } \\
\text { operates an open business } \\
\text { model, which helps master } \\
\text { changes and competitive } \\
\text { pressure. It sources key } \\
\text { activities from partners and } \\
\text { offers some of its own core } \\
\text { capabilities in non-core } \\
\text { contexts. }\end{array}$ & $\begin{array}{l}\text { "[...] firms can better } \\
\text { negotiate competitive } \\
\text { pressures by making the } \\
\text { boundaries of an } \\
\text { organization open and } \\
\text { more permeable to a } \\
\text { bidirectional flow of } \\
\text { innovative ideas. } \\
\text { According to } \\
\text { Chesbrough, there are } \\
\text { two types of openness: } \\
\text { 'outside in' and 'inside } \\
\text { out.". }\end{array}$ & $\begin{array}{l}\text { Production } \\
\text { (e.g., } \\
\text { fencing and } \\
\text { stone work } \\
\text { sourced } \\
\text { externally; } \\
\text { landscaping } \\
\text { provided } \\
\text { for existing } \\
\text { properties) }\end{array}$ \\
\hline $\begin{array}{l}\text { (Cheng, } \\
\text { 2011) }\end{array}$ & $\begin{array}{l}\text { A quantitative study on radical } \\
\text { service innovations is } \\
\text { conducted. It is shown that open } \\
\text { business models increase the } \\
\text { positive effect that the dynamic } \\
\text { service innovation capability } \\
\text { has on these innovations. }\end{array}$ & $\begin{array}{l}\text { "[...] an open business } \\
\text { model serves as an } \\
\text { organising principle for } \\
\text { structuring and } \\
\text { coordinating various } \\
\text { resources and functional } \\
\text { units [...]" }\end{array}$ & $\begin{array}{l}\text { New } \\
\text { service } \\
\text { develop- } \\
\text { ment and } \\
\text { delivery }\end{array}$ \\
\hline
\end{tabular}


Table 2 Continued

\begin{tabular}{|c|c|c|c|}
\hline Paper & Theme & OBM Perception & $\begin{array}{l}\text { Open } \\
\text { Activities }\end{array}$ \\
\hline $\begin{array}{l}\text { (Sandulli \& } \\
\text { Ches- } \\
\text { brough, } \\
\text { 2009a) }\end{array}$ & $\begin{array}{l}\text { Open business models } \\
\text { integrate external resources or } \\
\text { share internal resources with } \\
\text { others. The characteristics of } \\
\text { the resources determine the } \\
\text { type of open business model } \\
\text { that is appropriate. }\end{array}$ & $\begin{array}{l}\text { "Following this new } \\
\text { approach, companies are } \\
\text { beginning to share their } \\
\text { internal resources with a } \\
\text { third party to create } \\
\text { value, or the reverse, } \\
\text { companies are beginning } \\
\text { to incorporate external } \\
\text { resources in their own } \\
\text { business model. These } \\
\text { new business models } \\
\text { have been defined by } \\
\text { Chesbrough as open } \\
\text { business models." }\end{array}$ & $\begin{array}{l}\text { All } \\
\text { activities }\end{array}$ \\
\hline $\begin{array}{l}\text { (Purdy, } \\
\text { Robinson, } \\
\text { \& Wei, } \\
\text { 2012) }\end{array}$ & $\begin{array}{l}\text { Network-based open firm } \\
\text { models and business } \\
\text { ecosystems are on the rise. } \\
\text { Three models are proposed } \\
\text { that allow to profit from the } \\
\text { emerging opportunities. }\end{array}$ & $\begin{array}{l}\text { "[...] open business } \\
\text { models enable firms to } \\
\text { maximize the benefits of } \\
\text { openness while limiting } \\
\text { the risks." Synonymous } \\
\text { use with "open firm } \\
\text { business model" }\end{array}$ & $\begin{array}{l}\text { "Production, } \\
\text { consump- } \\
\text { tion or } \\
\text { innovation" }\end{array}$ \\
\hline $\begin{array}{l}\text { (Sheets \& } \\
\text { Crawford, } \\
\text { 2012) }\end{array}$ & $\begin{array}{l}\text { New technologies allow } \\
\text { improving the performance of } \\
\text { higher education by } \\
\text { unbundling the existing } \\
\text { business model. Economies } \\
\text { of scale can be achieved and } \\
\text { the learning experience can } \\
\text { be improved. }\end{array}$ & $\begin{array}{l}\text { "Open business models } \\
\text { involve the organizational } \\
\text { use of external as well as } \\
\text { internal ideas and } \\
\text { resources, and of external } \\
\text { as well as internal } \\
\text { pathways for deploying } \\
\text { them to create and } \\
\text { capture value." }\end{array}$ & $\begin{array}{l}\text { Curriculum } \\
\text { develop- } \\
\text { ment, } \\
\text { delivery } \\
\text { services, } \\
\text { infrastruc- } \\
\text { ture } \\
\text { manage- } \\
\text { ment }\end{array}$ \\
\hline $\begin{array}{l}\text { (Holm } \\
\text { et al., 2013) }\end{array}$ & $\begin{array}{l}\text { The effects of opening } \\
\text { business models in the Danish } \\
\text { newspaper industry are } \\
\text { examined. There are } \\
\text { downsides of open business } \\
\text { models (e.g., increased } \\
\text { dependency on partners); a } \\
\text { framework for classifying the } \\
\text { type of openness is proposed. }\end{array}$ & $\begin{array}{l}\text { Open business models are } \\
\text { explicitly defined in a } \\
\text { broad sense: "Although } \\
\text { based in part on } \\
\text { innovation management } \\
\text { research [... ], here we } \\
\text { expand [the concept of } \\
\text { openness] to the more } \\
\text { generic concept of a } \\
\text { business model." }\end{array}$ & $\begin{array}{l}\text { Value } \\
\text { creation, } \\
\text { delivery } \\
\text { and capture }\end{array}$ \\
\hline
\end{tabular}


Table 2 Continued

\begin{tabular}{|c|c|c|c|}
\hline Paper & Theme & OBM Perception & $\begin{array}{l}\text { Open } \\
\text { Activities }\end{array}$ \\
\hline $\begin{array}{l}\text { (Storbacka, } \\
\text { Frow, Nenonen, } \\
\text { \& Payne, 2012) }\end{array}$ & $\begin{array}{l}\text { In today's economy, different } \\
\text { actors jointly create value by } \\
\text { integrating their resources. To } \\
\text { be successful, the business } \\
\text { model of a focal actor needs } \\
\text { not only be aligned internally } \\
\text { but also with the business } \\
\text { models of external partners. }\end{array}$ & $\begin{array}{l}\text { "Business models are } \\
\text { typically designed around } \\
\text { over-riding design themes } \\
\text { [...].We suggest that one } \\
\text { over-riding theme can be } \\
\text { 'co-creation' and argue } \\
\text { that a focal actor wishing } \\
\text { to engage in co-creation } \\
\text { needs to design an 'open' } \\
\text { business model that } \\
\text { permits other actors to } \\
\text { influence specific design } \\
\text { elements." }\end{array}$ & $\begin{array}{l}\text { All value } \\
\text { creation } \\
\text { activities } \\
\text { (not } \\
\text { detailed) }\end{array}$ \\
\hline $\begin{array}{l}\text { (Frankenberger, } \\
\text { Weiblen, \& } \\
\text { Gassmann, } \\
\text { 2013) }\end{array}$ & $\begin{array}{l}\text { Product companies can } \\
\text { become solution providers } \\
\text { through complementing their } \\
\text { products with services } \\
\text { provided by partner firms. } \\
\text { The customer centricity of the } \\
\text { focal firm's business model } \\
\text { and the characteristics of the } \\
\text { partner network have to } \\
\text { match to achieve firm } \\
\text { success. Three successful } \\
\text { constellations are presented. }\end{array}$ & $\begin{array}{l}\text { "Researchers on open } \\
\text { business models outline } \\
\text { even more explicitly the } \\
\text { need for external } \\
\text { collaboration by arguing } \\
\text { that open business models } \\
\text { lead to value creation and } \\
\text { capturing by } \\
\text { 'systematically } \\
\text { collaborating with outside } \\
\text { partners' (Osterwalder } \\
\text { and Pigneur 2010: 109)." }\end{array}$ & $\begin{array}{l}\text { Solution } \\
\text { production } \\
\text { and } \\
\text { delivery }\end{array}$ \\
\hline
\end{tabular}

One very central notion herein is the concept of the ecosystem (nine papers). A (business/industry) ecosystem describes the surroundings of a focal firm, into which it is embedded. It contains the stakeholders of a company, which are first and foremost its customers and suppliers (Sandulli \& Chesbrough, 2009b), but also its industry peers (Chu \& Chen, 2011), as well as managers, innovators, and workers (Purdy et al., 2012). The contribution of the open business model here is to explicitly consider the ecosystem as a new source of value creation and capturing by developing symbiotic relationships (Romero \& Molina, 2011) and emphasizing inter-organizational activities (Chu \& Chen, 2011). The notion of opening a firm's borders to the outside world is prominently found in the reviewed literature.

Another prominent concept is that of value- or partner networks (nine papers). Holm et al. (2013, p.327) define a partner network as a "network of cooperative agreements with other companies needed to efficiently offer 
and commercialize value". Similarly, a value network is seen as a new and flexible setup of value co-creation that replaces the linear value chain logic (Romero \& Molina, 2011; Storbacka et al., 2012). Setting up a beneficial value network is found to be a critical part of an open business model (Davey et al., 2011), just as partner network characteristics can determine open business model performance (Frankenberger et al., 2013). Overall, the notion that value creation happens together with partners in a value network seems to be a central feature of an open business model.

Two further terms are frequently mentioned in the context of open business models: plaforms (nine papers, not counting four that mean web platforms for collaboration purposes) and alliances (ten papers). Platforms are based on technology assets which the platform owner or "sponsor" (Sandulli \& Chesbrough, 2009b) opens up for typically smaller partners (Purdy et al., 2012), enabling them to create additional value on top and connect with customers (Luo \& Chang, 2011). This type of open business model allows the platform owner to influence its entire industry (Chu \& Chen, 2011; Sandulli \& Chesbrough, 2009b). The second concept, alliances, is used twofold. On the one hand, it relates to the inter-organizational legal manifestation of partnerships in the form of strategic alliances, joint ventures, or consortia (Y. Wang \& Zhou, 2012). On the other hand, it is used in relation to the generic challenges and logic of managing partnerships (Enkel, Gassmann, \& Chesbrough, 2009). Both usages mark interesting aspects that are core considerations in open business model implementation.

\subsubsection{Unit of analysis in open business model research}

Despite the literature base's explicit consideration of networks and ecosystems, there is a strong commonality between all papers across both streams: the unit of analysis for the authors is the firm. As part of an open business model, no paper analyzes the joint value proposition of the value network or its common value capturing mechanism - rather, a focal firm is at the center of the analysis (Alexy \& George, 2011; Frankenberger et al., 2013; Holm et al., 2013), which even needs to provide a separate value proposition to every partner that it collaborates with (Storbacka et al., 2012). The focal firm and its relationships with the ecosystem are what open business model scholars are interested in. Even if all firms within a value network are analyzed (Smith et al., 2010), they are perceived as independent units with their individual agendas and activities. What is to be considered by the focal firm in designing its open business model, however, is its fit with the business models of the other actors in its value network (Chesbrough \& Schwartz, 2007; Storbacka et al., 2012). 


\subsubsection{Business model innovation - "opening" the business model}

A very common theme in the analyzed literature base is the notion of "opening" the business model. More or less implicitly, most authors assume a closed business model as the starting point and an open business model as the desirable end state of firm transformation. This change process of implementing adjustments to an existing business model falls into the field of business model innovation, which sees innovation to the business model as a different task than product and process innovation (Amit \& Zott, 2012; Schneider \& Spieth, 2013). With eleven of the 24 papers explicitly bringing up business model innovation and five of them doing so implicitly, the idea that the business model itself can be subject to innovation seems to be more prominent in open business model research than in "normal" business model research (Smith et al., 2010). The move from a closed to an open business model is seen as particularly challenging and requiring more research insights (Storbacka et al., 2012). Due to the lack of a knowledge base in this field, Chesbrough (2007) openly encourages practitioners to experiment with open business models to determine the best solution.

\subsubsection{Further common themes}

Closing the analysis of open business model literature, two further observations are worth mentioning. First, partially in supporting the move towards open business models, scholars pay special attention to challenges that are specific to firms implementing these models. Apart from technical challenges (Kakaletris et al., 2004), this field includes diverse managerial issues such as leadership (Smith et al., 2010), incentivation (Chanal \& Caron-Fasan, 2010), absorptive capacity (Sandulli \& Chesbrough, 2009b), local cultural issues (Purdy et al., 2012), or trust (Romero \& Molina, 2011). Second, a number of authors develop classification schemes and frameworks which further subdivide the open business model into different archetypes. These accommodate for observed differences in real-world cases (Alexy \& George, 2011; Purdy et al., 2012; Sheets \& Crawford, 2012; Wang et al., 2009) or are based on different degrees of openness (Frankenberger et al., 2013; Holm et al., 2013; Sandulli \& Chesbrough, 2009b).

\section{Clarifying the Open Business Model}

Based on the extensive review of literature, three issues can be identified which affect the conceptual clarity of the open business model: (1) its unclear 
definition that breaks up into two streams; (2) its similarity to open innovation; and (3) its similarity to the business model concept itself. In this section, these points are resolved to arrive at a clearer picture of the open business model's nature. To do so, additional literature and real-world cases from the literature base are used to illustrate the points made. The resulting framework allows drawing the lines between the overlapping concepts and clarifies their relationships.

\subsection{Reconciling Both Views of the Open Business Model}

As was diagnosed as part of the literature analysis, the open business model literature falls into two streams. While the open innovation view considers openness in a focal firm's research and development as the decisive factor that accounts for an open business model, the business model view considers openness in all value creation and value capturing activities. While the open innovation view focuses on ideas, knowledge, and intellectual property as items exchanged in novel ways (Chesbrough, 2007), the business model view takes a very broad perspective of "resources" that are exchanged and shared with the ecosystem (Sandulli \& Chesbrough, 2009b; Storbacka et al., 2012). Scholars here include not only typical resources such as production assets, but also skills, services, and brand. Overall, the business model view is broader than the open innovation view; Figure 2 illustrates the findings based on the earlier literature review as summarized in Tables 1 and 2 .

It becomes clear from the above that both views of the open business model are not directly opposing. Rather, the more narrow open innovation view is contained within the broader business model view. Recollecting the common themes, what would speak for either view? The reviewed literature reveals that an open business model is seen as an ecosystem-aware way of

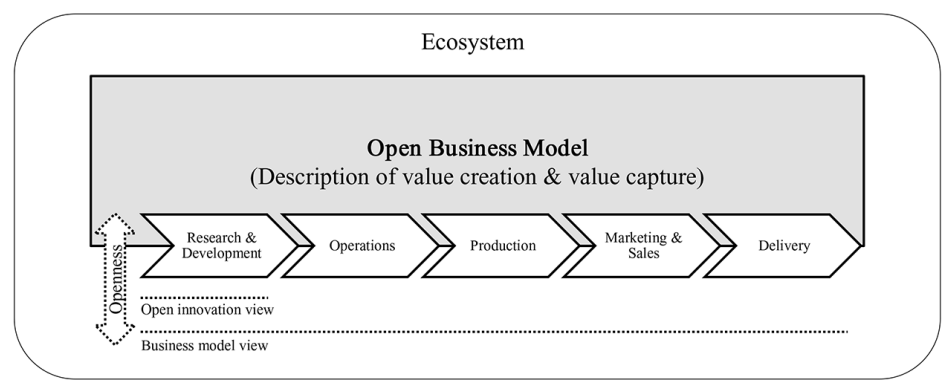

Figure 2 Openness with regard to value creation activities in the open innovation and business model views of the open business model. 
value creation and capturing. Focal firms collaborate with the ecosystem by building up value- or partner networks, platforms, or alliances and innovate their business model to make use of the emerging opportunities.

The narrow view might owe its prominence to the fact that $R \& D$ activities of a firm are typically internally focused and closed (Chesbrough, 2007). Introducing openness in this area might lead to more surprising and innovative results, and thus scholarly attention. But would a company like 3M Services, which builds up a network of service delivery partners to enter the market for solutions (Frankenberger et al., 2013), not face similar challenges with regards to its business model as Procter\&Gamble, which builds up a network of R\&D partnerships to discover interesting product ideas (Chesbrough, 2007)? I do not see a special role of R\&D activities in the overall story and, in the light of the common themes identified, feel that results of open business model research could benefit firms in opening up any activity for collaboration. Hence, I argue in favor of adopting the broader view and to consider openness in any value creation or capturing activity as a necessary condition for an open business model.

Assertion 1: An open business model includes external resources in at least one of its value creation and capturing activities.

\subsection{The 'Open Business Model - Open Innovation' Relationship}

Opting for the business model view of the open business model implies that there are open business models not implementing open innovation principles, which some of the reviewed papers seem to suggest differently. Cases such as the 29 Costa Rican textile companies, which partner in their marketing and branding efforts (Sandulli \& Chesbrough, 2009b), or the aforementioned 3M Services case, where service partners enable solution delivery (Frankenberger et al., 2013), are just two examples of open business models not directly based on open innovation principles. The other way round, however, is not clear yet: does a firm that follows the open innovation concept automatically possess an open business model? To clarify this relationship, a closer look at open innovation is required.

Based on the idea of opening R\&D to the purposive inflow and outflow of ideas (Chesbrough, 2006b), a number of different phenomena have been filed under the open innovation umbrella and the concept has developed into an established field of research (Gassmann, Enkel, et al., 2010). Structuring the field, scholars typically differentiate between outbound and inbound innovation, depending on the direction of idea flow. Dahlander \& Gann (2010) 
add an additional dimension, the pecuniary aspect, when reviewing the extant literature base. In the context of open business models and value capturing mechanisms that they include, the Dahlander \& Gann (2010) framework might prove helpful in structuring open innovation phenomena and ensuring completeness.

Firms revealing their ideas or knowledge to the outside world without a direct financial reward (“outbound-revealing" as per Dahlander \& Gann, 2010) can do so, for example, to attract complementors whose offerings make their own product more attractive. Computer game producer Valve, which allows others to develop games based on its own technology, is an example here (Jeppesen \& Molin, 2003). In Valve's case, openness is clearly a cornerstone of the business model's value creation and capturing logic and ensures the firm's sustained success. In other cases, however, the business model relationship is not so obvious. Not any open innovation move constitutes an open business model and value capturing is a major problem in this class of open innovations (Dahlander \& Gann, 2010). When Netscape, for example, released the source code of its Navigator web browser, this was more a strategic one-time move against Microsoft's dominance (Alexy \& George, 2011) than the basis of a sustainable new business model. Sustainability is a common theme of many business model definitions (Zott et al., 2011) and, together with the value capturing argument, might serve as a distinguishing feature. Formally:

Assertion 2:Open innovation only constitutes an open business model if it contributes to the firm's sustained value creation and capturing.

Selling or otherwise commercializing ideas ("outbound-selling" as per Dahlander \& Gann, 2010) ensures value capturing and is a classic theme in business model literature (e.g., Chesbrough \& Rosenbloom, 2002). But are all intellectual property-based business models examples for open business models? As soon as a firm's purpose is in creating intellectual property for licensing or sale, ideas become a product - and selling products is not what constitutes an open business model as per the previous findings. The chip design house ARM, for example, develops microprocessor architectures and licenses them to chip manufacturers. Its business model would not fall into the open business model category due to a lack of external resources used (cp. Assertion 1) - if not, in developing the technology, "close interaction with co-producers" would be a "central feature of ARM's business model" (Garnsey, Lorenzoni, \& Ferriani, 2008, p. 220).

A major share of open innovation scholars studies the inbound direction of idea flow (Enkel et al., 2009), both pecuniary and non-pecuniary. In both categories ("inbound-souring" and "inbound-acquiring" as per Dahlander \& 
Gann, 2010), external ideas are sourced from suppliers, customers, competitors, intermediaries, universities or, more broadly, the ecosystem. These relationships of the focal firm with the idea source can form the basis of long-lasting and vital partnerships (Dyer \& Singh, 1998), leading to joint value creation and thus open business models. Yet, open innovation literature on the inbound direction also provides opposing examples. In the case of Hilti's fleet management, for instance, the tool manufacturer transferred the idea for its fleet management concept from the automotive industry (Enkel \& Gassmann, 2010). Despite clearly resulting in an innovative business model (Johnson, Christensen, \& Kagermann, 2008), openness in terms of relationships or resource exchange with external partners was not part of the new logic. Many of the 24 other open innovation cases described by Enkel \& Gassmann (2010) demonstrate the power of inbound open innovation in creating new products and solving technical challenges - only a few of them could, however, be considered open business models in the spirit of joint value creation and capturing. This notion is confirmed by Chu \& Chen (2011), who separate the concepts as follows: "Excluding the external R\&D viewpoint of open innovation, open business models emphasize the inter-organizational activities" (Chu \& Chen, 2011, p. 8538).

Assertion 3: Open innovation only constitutes an open business model if it leads to collaboration in the firm's value creation and capturing activities.

As the above examples illustrate, incorporating open innovation into research and development does not necessarily establish an open business model. Although open innovation often necessitates business model changes to reap its benefits (Chesbrough, 2007; Smith et al., 2010), the result is not always an open business model. The underlying reason for this paradox is the different meaning of openness in both concepts: open innovation looks at the permeability of a firm's research and development for ideas, whereas open business models look at collaborative value creation and capturing. The openness required is not always the same or, as Holm et al. (2013, p. 341) put it, "openness to innovations and openness of business models needs to be adequately recognized, understood, and treated as separate phenomena."

\subsection{The 'Open Business Model - Business Model' Relationship}

As the literature review and discussion so far revealed, an open business model can be open in its every aspect, whereby the term "open" relates to joint value capturing and creation with partners in the ecosystem. This notion of openness is not new to the business model concept. In fact, it is so deeply engrained that 
some of the leading scholars in the field have included it into their business model definitions (Osterwalder, Pigneur, \& Tucci, 2005; Weill \& Vitale, 2001; Zott et al., 2011). Shafer, Smith, \& Linder (2005, p. 202), for instance, define the business model as "a representation of a firm's underlying core logic and strategic choices for creating and capturing value within a value network." This section hence tries to clarify the relation between the business model and its open variant, as well as the benefits that a separate open concept could have.

The main difference that comes to mind is the obligation for openness in the open business model. While the generic term "business model" allows for collaborative and non-collaborative ways of value creation and capturing, "open" explicitly calls for the inclusion of partners. The role of the open business model might hence be to explain those business models which include partnerships and to focus on those aspects that are of particular relevance in such types of business models. Potentially this is what Storbacka et al. (2012, p. 72) have in mind when they state that "most of the extant research on business models has been firm-centric, whereas this research adopts a networkcentric view." Might this perception prove useful in describing business reality?

There is reason to believe that, in today's networked economy, there is hardly any firm that does not collaborate with its ecosystem in one way or another. Classifying a closed business model as one that does not permit collaboration - and all others as open - would result in a world of open business models and hence not differentiate both concepts. Considering openness as a continuum (Dahlander \& Gann, 2010; Sandulli \& Chesbrough, 2009b), a way to decide if an observed degree of openness is sufficient to characterize a business model as "open" is needed. The business model concept itself might provide such a mechanism, as it is seen as an "abstraction" (Casadesus-Masanell \& Ricart, 2010; Osterwalder et al., 2005) or "high-level representation" (Bock, Opsahl, George, \& Gann, 2012) of the firm. As is the case with all abstractions, certain levels of detail are lost during the process. The criterion could hence be: Is the openness required to explain the firm's value creation and capturing logic on a business model level? If so, the business model is open. If the collaborative aspect gets lost during abstraction, the label "open" should be omitted. Openness and collaboration with the ecosystem should, in this context, be seen as going beyond simple interactions such as sourcing from suppliers or selling to customers.

The case of BMW might illustrate this idea. In a case frequently cited in open innovation literature, the company collaborated with a high-tech 
company in the early development of its iDrive onboard control system (Gassmann, Zeschky, Wolff, \& Stahl, 2010). The collaborative aspect is clearly fulfilled here - yet, I suspect that the partnership would not appear in any description of BMW's overall business model. Consequently, the business model would not be called open. Considering BMW's business as an automotive OEM, however, a huge amount of collaboration with its value network of suppliers and development partners can be expected to occur typically, these partners account for more than 70\% of a car's value (Quesada, Syamil, \& Doll, 2006). Considering this context, one might well term BMW's business model "open", since its overall network of partners would surely be included in the description of its business model. Hence, another requirement for the open business model concept is proposed.

Assertion 4: In an open business model, openness in terms of collaboration is so central to the firm's current logic of value creation and capturing that it could not be explained without it.

With this criterion, a guideline exists for a user of the concept to classify a business model as open or not - although it admittedly does not differentiate clearly and objectively. Two reasons can be given for this. First, the aforementioned nature of openness as a continuum impedes differentiation without a reference point - a relative "more open than" is easier to determine than an absolute "open". Second, the level of abstraction in a business model is not clear either, and it is thus in the eyes of the beholder to judge whether the observed openness is required to explain value creation and capturing in a concrete setting. Further contextual arguments might be considered in this judgment, such as the degree of openness of prevalent business models in the firm's industry. The previous remarks also imply that "not open" in the sense of an open business model does not equal to "closed". The border between "open" and "closed" is broad and there are many shades of grey, whereby the open business model captures those clear cases in which openness is a distinctive feature of a business model.

Another point to be discussed is the use which a separate open business model concept has for research. Despite (or due to) the holistic picture of the firm that the business model provides, scholars using the concept tend to focus on the set of aspects that is relevant in their particular context (George \& Bock, 2011). The common themes identified in the reviewed literature base, such as the challenges involved in establishing partnerships and in achieving fit between business models, show that there are many aspects particular to open business models. These mark a separate area of business model research which might require special theoretical lenses of analysis, such as absorptive capacity 
(Sandulli \& Chesbrough, 2009b), network theory (Frankenberger et al., 2013), or transaction costs (Chu \& Chen, 2011). Bundling these specifics into a subclass of business model research would, as per my perception, help focus and advance research in this field. In line with the authors in the literature base, who have used the concept for a purpose, the open business model should be seen and used as a self-contained subclass of business models.

\subsection{Conceptual Framework of the Open Business Model}

Viewing the previous sections and the four assertions made in context allows to draw up a conceptual framework that can be used to illustrate the relationships of open innovation, business models, and open business models. In summary:

- Open innovation describes purposeful openness of a firm's research \& development activities.

- Business models describe the sustained value creation and capturing of a firm, independent of openness.

- Open business models are a subclass of business models in which collaboration plays a central role in explaining value creation and capturing of a focal firm.

Since the three constructs overlap, the case base established above shall illustrate the overlapping areas. Figure 3 presents the illustration of the argument.

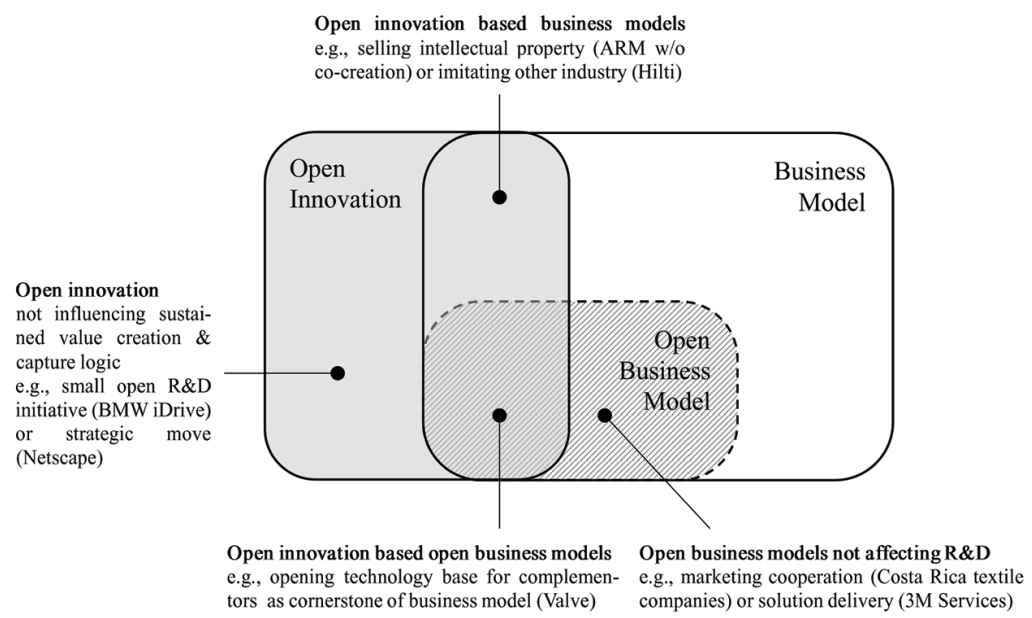

Figure 3 Conceptual framework of separation and overlap between open innovation, business model, and open business model concepts 
The framework builds upon the main differentiation criteria and assertions that were elaborated in the earlier discussion of the concepts. Re-stating and summarizing them here shall help consolidate the findings:

- Open innovation only falls together with the business model concept if it contributes to a firm's sustained value creation and value capturing.

- Open innovation only falls together with the open business model concept if it leads to collaboration as a central part of the business model.

- A business model is open only if the aspect of collaboration (i.e., joint value creation and capturing with partners) is central in explaining the overall logic of value creation and capturing.

Building on the prior definition of Teece (Teece, 2010, p. 191), this section concludes with a proposed definition of the open business model in line with the above findings: An open business model describes the design or architecture of the value creation and value capturing of a focal firm, in which collaborative relationships with the ecosystem are central to explaining the overall logic.

\section{Summary and Conclusions}

In line with the purpose of this paper to investigate and clarify the nature of the open business model, the concept has been approach based on an extensive review of scholarly literature. Despite a large overlap in many common themes (such as collaboration, partnerships, business model innovation, and challenges of openness), the concept's definition and usage in the literature base was found unclear and inconsistent. In this respect, the open business model suffers from similar deficiencies as the business model concept itself (George \& Bock, 2011; Zott et al., 2011). The lack of conceptual clarity of the open business model can be traced back to three root causes: (1) its unclear definition that breaks up into two streams; (2) its similarity to open innovation; and (3) its similarity to the business model concept itself. The attempt to resolve these tensions by consulting additional literature from the open innovation and business model fields results in a framework that illustrates the relationships of the three overlapping concepts. A set of differentiation criteria is provided which helps in relating real-world cases to the three constructs. In essence, the findings suggest considering the open business model as a subclass of the business model concept in which collaboration plays a central role in the value creation and capturing activities of a focal firm.

The presented study is the first to conduct a systematic review of prior literature on the open business model specifically. Although the base of 
high-class scholarly work on the topic is still limited at this point of time, the field shows first signs of fragmentation. Many scholars use the concept without clear definition, resulting in divergence of perception and overlap with existing concepts. This paper's comprehensive perspective helps in sharpening the perception and future usage of the open business model in the research community. The achieved clarity in meaning and relations to the open innovation and business model fields should lead to a more focused and deliberate use in future work. The remaining - now clearly defined - overlap with open innovation and business model research should not be seen as a weakness of the open business model concept. Rather, findings in these more established fields can serve as the base on which open business model research can grow and develop. Its strength lies in integrating these perspectives into a new concept of its own right.

It is a noteworthy limitation of this paper to not have included potentially similar concepts, such as collaborative and networked business models, into the analysis. While this approach proved helpful in unraveling the core of the "open business model", literature under similar labels might hold valuable insights which have been missed. Future research could take the achieved understanding of the open business model as the basis for an exploration of commonalities and differences with those similar business model concepts.

With regards to the practical use of the open business model, the reviewed literature suggests two conclusions. First, there definitely are a growing number of business models in the real world that are built upon novel ways of interaction with the business ecosystem and partnerships with other entities. These business models currently lack a systematic means of description and analysis, which the open business model could provide. Second, there is a lack of guidance for managers as to how these open business models can be achieved in newly founded or established firms. The field of business model innovation in the context of open business models describes the innovation processes, organizational implications, and managerial challenges of opening up a firm's business model and making collaboration a central part of its value creation and capturing logic. It presents a promising route for future research which has high relevance for practice (see Lindgren \& Jørgensen, 2012; Lindgren, Taran, \& Boer, 2010).

More insights are also needed in studying the open business model's consequences for the focal firm - under which circumstances is it advisable to adopt an open business model at all? Holm et al. (2013) make this important point, suspecting a "pro-bias" in current literature. More quantitative research on performance aspects (such as Cheng, 2011) and financial implications (such 
as Alexy \& George, 2011) would help with these topics. Considering an open business model's task of explaining collaborative value creation and capturing, the value capturing aspect is rarely covered in the reviewed literature (Chanal \& Caron-Fasan, 2010 are an exception here). Different modes of value appropriation and partner motivation in network-centric business models hence mark another avenue for research in which the open business model could prove its use as an analytical device. The research field might also benefit from a stronger use of existing theories to explain the observed phenomena; scholars in the reviewed literature mention dynamic capabilities (Cheng, 2011), absorptive capacity (Sandulli \& Chesbrough, 2009b), or network theory (Frankenberger et al., 2013) as being valuable. Future contributions in the open business model field should observe these proposals and assess their applicability.

Clearly, the increasingly networked economy (Ehret \& Wirtz, 2010; IBM Global Business Services, 2012) provides many more real-world phenomena and topics than mentioned here which would be worth studying, categorizing, and classifying from an open business model perspective. Research on open business models has just begun and, provided consistency in the concept's usage, has the potential of developing into a vibrant research field of high practical relevance.

\section{Acknowledgements}

An earlier version of this paper has been presented at the EURAM 2013 conference in Istanbul. The author wants to thank the reviewers and discussants of that conference, as well as the two anonymous reviewers and editor Peter Lindgren of the Journal of Multi Business Model Innovation and Technology for their very valuable comments.

\section{References}

[1] Alexy, O., \& George, G. (2011). Category Creation in Open Business Models and Its Implications for Firm Value, SSRNAccepted Paper Series, no. 1019527, Forthcoming in the Journal of Management Studies.

[2] Amit, R., \& Zott, C. (2012). Creating Value through Business Model Innovation. MIT Sloan Management Review, 53(3), 41-49.

[3] Bock, A. J., Opsahl, T., George, G., \& Gann, D. M. (2012). The Effects of Culture and Structure on Strategic Flexibility during Business Model Innovation. Journal of Management Studies, 49(2), 279-305. 
[4] Bougant, F., Delmond, F., \& Pageot-Millet, C. (2003). The user profile for the virtual home environment. IEEE Communications Magazine, January, 93-98.

[5] Casadesus-Masanell, R., \& Ricart, J. E. (2010). From Strategy to Business Models and onto Tactics. Long Range Planning, 43(2-3), 195-215.

[6] Chanal, V., \& Caron-Fasan, M.-L. (2010). The Difficulties involved in Developing Business Models open to Innovation Communities: the Case of a Crowdsourcing Platform. $M @ n @ g e m e n t, 13(4), 318-341$.

[7] Cheng, C. (2011). Dynamic service innovation capability, radical service innovation and open business models. International Journal of Services Technology and Management, 16(3/4), 229-242.

[8] Chesbrough, H. W. (2003). Open Innovation: The New Imperative for Creating and Profiting from Technology. Cambridge, MA: Harvard Business School Publishing.

[9] Chesbrough, H. W. (2006a). Open Business Models: How to Thrive in the New Innovation Landscape. Boston, MA: Harvard Business School Press.

[10] Chesbrough, H. W. (2006b). Open Innovation: A New Paradigm for Understanding Industrial Innovation. In H. W. Chesbrough, W. Vanhaverbeke, \& J. West (Eds.), Open Innovation: Researching a New Paradigm (Vol. 21, pp. 1-12). Oxford University Press.

[11] Chesbrough, H. W. (2007). Why Companies Should Have Open Business Models. MIT Sloan Management Review, 48(2), 22-28.

[12] Chesbrough, H. W., \& Rosenbloom, R. S. (2002). The role of the business model in capturing value from innovation: evidence from Xerox Corporation's technology spin-off companies. Industrial and Corporate Change, 11(3), 529-555.

[13] Chesbrough, H. W., \& Schwartz, K. (2007). Innovating business models with co-development partnerships. Research-Technology Management, 50(1), 55-59.

[14] Chu, P.-Y., \& Chen, W.-C. (2011). Open business models: A case study of System-on-a-Chip (SoC) design foundry in the integrated circuit (IC) industry. African Journal of Business Management, 5(21), 8536-8544.

[15] Dahlander, L., \& Gann, D. M. (2010). How open is innovation? Research Policy, 39(6), 699-709.

[16] Davey, S. M., Brennan, M., Meenan, B. J., \& McAdam, R. (2010). The Health of Innovation: Why Open Business Models Can Benefit the Healthcare Sector. Irish Journal of Management, 30(1), 21-40. 
[17] Davey, S. M., Brennan, M., Meenan, B. J., \& McAdam, R. (2011). Innovation in the medical device sector: an open business model approach for high-tech small firms. Technology Analysis \& Strategic Management, 23(8), 807-824.

[18] Dijkstra, F., van Oudenaarde, B., Andree, B., Gommans, L., van der Ham, J., Koymans, K., \& de Laat, C. (2005). Control Models at Interconnection Points. Amsterdam, NL.

[19] Dyer, J. H., \& Singh, H. (1998). The relational view: Cooperative strategy and sources of interorganizational competitive advantage. Academy of Management Review, 23(4), 660-679.

[20] Ehret, M., \& Wirtz, J. (2010). Division of Labor between Firms: Business Services, Non-Ownership-Value and the Rise of the Service Economy. Service Science, 2(3), 136.

[21] Enkel, E., \& Gassmann, O. (2010). Creative imitation: exploring the case of cross-industry innovation. R\&D Management, 40(3), 256-270.

[22] Enkel, E., Gassmann, O., \& Chesbrough, H. W. (2009). Open R\&D and open innovation: exploring the phenomenon. $R \& D$ Management, 39(4), 311-316.

[23] Frankenberger, K., Weiblen, T., \& Gassmann, O. (2013). Network configuration, customer centricity, and performance of open business models: A solution provider perspective. Industrial Marketing Management, 42(5), 671-682.

[24] Garnsey, E., Lorenzoni, G., \& Ferriani, S. (2008). Speciation through entrepreneurial spin-off: The Acorn-ARM story. Research Policy, 37(2), 210-224.

[25] Gassmann, O., Enkel, E., \& Chesbrough, H. W. (2010). The future of open innovation. R\&D Management, 40(3), 213-221.

[26] Gassmann, O., Zeschky, M., Wolff, T., \& Stahl, M. (2010). Crossing the Industry-Line: Breakthrough Innovation through Cross-Industry Alliances with "Non-Suppliers." Long Range Planning, 43(5-6), 639-654.

[27] George, G., \& Bock, A. J. (2011). The Business Model in Practice and its Implications for Entrepreneurship Research. Entrepreneurship Theory and Practice, 35(1), 83-111.

[28] Holm, A. B., Günzel, F., \& Ulhøi, J. P. (2013). Openness in innovation and business models: lessons from the newspaper industry. International Journal of Technology Management, 61(3/4), 324-348.

[29] IBM Global Business Services. (2012). Leading Through Connections: Insights from the global CEO study. Somers, NY. 
[30] Jagoda, K., Maheshwari, B., \& Gutowski, G. (2012). Deer Creek Land Development (DCLD): Open business model approach to sustaining competitive advantage. International Journal of Commerce and Management, 22(2), 133-144.

[31] Jeppesen, L. B., \& Molin, M. J. (2003). Consumers as co-developers: Learning and innovation outside the firm. Technology Analysis \& Strategic Management, 15(3), 363-383.

[32] Johnson, M. W., Christensen, C. M., \& Kagermann, H. (2008). Reinventing Your Business Model. Harvard Business Review, 86(12), 50-59.

[33] Kakaletris, G., Varoutas, D., Katsianis, D., Sphicopoulos, T., \& Kouvas, G. (2004). Designing and Implementing an Open Infrastructure for Location-Based, Tourism-Related Content Delivery. Wireless Personal Communications, 30(2-4), 153-165.

[34] Lindgren, P., \& Jørgensen, R. (2012). Towards a Multi Business Model Innovation Model. Journal of Multi Business Model Innovation and Technology, 1(1), 1-22.

[35] Lindgren, P., Taran, Y., \& Boer, H. (2010). From single firm to network-based business model innovation. International Journal of Entrepreneurship and Innovation Management, 12(2), 122-137.

[36] Luo, C.-M., \& Chang, H.-F. (2011). SME competitive strategy: learning from Taiwan's ODM industry. Business Strategy Series, 12(3), 107-114.

[37] Morris, M., Schindehutte, M., \& Allen, J. (2005). The entrepreneur's business model: toward a unified perspective. Journal of Business Research, 58(6), 726-735.

[38] Osterwalder, A., Pigneur, Y., \& Tucci, C. L. (2005). Clarifying business models: Origins, present, and future of the concept. Communications of the Association for Information Systems, 16(1), 1-25.

[39] Pereira, J. M. (2001). Reconfigurable Radio: the evolving perspectives of different players. In 12th IEEE International Symposium on Personal, Indoor and Mobile Radio Communications. PIMRC 2001. Proceedings (pp. C-79-C-84). IEEE.

[40] Purdy, M., Robinson, M. C., \& Wei, K. (2012). Three new business models for "the open firm." Strategy \& Leadership, 40(6), 36-41.

[41] Quesada, G., Syamil, A., \& Doll, W. J. (2006). OEM New Product Development Practices: The Case of the Automotive Industry. The Journal of Supply Chain Management, 42(3), 30-40.

[42] Romero, D., \& Molina, A. (2011). Collaborative networked organisations and customer communities: value co-creation and co-innovation in the networking era. Production Planning \& Control, 22(5-6), 447-472. 
[43] Sandulli, F. D., \& Chesbrough, H. W. (2009a). Open Business Models: Las dos caras de los Modelos de Negocio Abiertos. Universia Business Review, 22, 12-39.

[44] Sandulli, F. D., \& Chesbrough, H. W. (2009b). The two faces of open business models. SSRN working paper series, no. 1325682.

[45] Schneider, S., \& Spieth, P. (2013). Business Model Innovation: Towards an Integrated Future Research Agenda. International Journal of Innovation Management, 17(1), 1-34.

[46] Shafer, S. M., Smith, H. J., \& Linder, J. C. (2005). The power of business models. Business Horizons, 48(3), 199-207.

[47] Sheets, R., \& Crawford, S. (2012). Harnessing the Power of Information Technology: Open Business Models in Higher Education. EDUCAUSE Review, 47(2), 34-48.

[48] Smith, P., Cavalcante, S., Kesting, P., \& Ulhøi, J. P. (2010). Opening Up the Business Model: A Multi-dimensional View of Firms' Inter-organizational Innovation Activities. In Proceedings of the 11th International CI-Net Conference (pp. 1-13). Zürich, CH.

[49] Soloviev, V. I., Kurochkin, P. A., Rendiuk, A. V., \& Zazuk, A. V. (2010). Innovative business models in the media industry. Annales Universitatis Apulensis Series Oeconomica, 12(2), 692-697.

[50] Storbacka, K., Frow, P., Nenonen, S., \& Payne, A. (2012). Designing business models for value co-creation. In S. L. Vargo \& R. F. Lusch (Eds.), Special Issue - Toward a Better Understanding of the Role of Value in Markets and Marketing (Review of Marketing Research, Volume 9) (pp. 51-78). Emerald Group Publishing Limited.

[51] Teece, D. J. (2010). Business Models, Business Strategy and Innovation. Long Range Planning, 43(2-3), 172-194.

[52] Vetter, P., Fredricx, F., Rajan, G., \& Oberle, K. (2008). Recommendations for a Multi-Service Access Architecture from the European MUSE Project. Bell Labs Technical Journal, 13(1), 11-28.

[53] Vom Brocke, J., Simons, A., Niehaves, B., Riemer, K., Plattfaut, R., \& Cleven, A. (2009). Reconstructing the giant: on the importance of rigour in documenting the literature search process. In Proceedings of the 17th European Conference on Information Systems (pp. 1-13).

[54] Wang, L., Jaring, P., \& Arto, W. (2009). Developing a conceptual framework for business model innovation in the context of open innovation. In Proceedings of the 3rd IEEE International Conference on Digital Ecosystems and Technologies (pp. 460-465). Ieee. 
[55] Wang, Y., \& Zhou, Z. (2012). Can open innovation approach be applied by latecomer firms in emerging countries? Journal of Knowledge-based Innovation in China, 4(3), 163-173.

[56] Webster, J., \& Watson, R. T. (2002). Analyzing the past to prepare for the future: Writing a literature review. MIS Quarterly, 26(2), xiii-xxiii.

[57] Weill, P., \& Vitale, M. R. (2001). Place to Space: Migrating to e-Business Models. Boston, MA: Harvard Business School Press.

[58] Zott, C., Amit, R., \& Massa, L. (2011). The Business Model: Recent Developments and Future Research. Journal of Management, 37(4), 1019-1042.

\section{Appendix}

\subsection{Overview of Literature Search Results and Research Designs}

The literature search was conducted in the October/November 2012 timeframe, with additional rounds in December 2012 and January 2013 to accommodate for newly published contributions. The aim was to capture the available literature as per the end of 2012 .

\subsubsection{Search A: EBSCO Discovery Service}

Search for "open business model*" in title, abstract, or keywords of peer-reviewed journals. Obvious duplicates, non-English articles, nonscholarly articles, and book reviews excluded. Result set:

\begin{tabular}{|c|c|c|}
\hline Paper & Research type & Research design / Data base \\
\hline $\begin{array}{l}\text { (Chanal \& Caron-Fasan, } \\
\text { 2010) }\end{array}$ & $\begin{array}{l}\text { Qualitative } \\
\text { empirical }\end{array}$ & $\begin{array}{l}\text { Single-case study (longitudinal): } \\
\text { crowdsourcing platform }\end{array}$ \\
\hline (Cheng, 2011) & $\begin{array}{l}\text { Quantitative } \\
\text { empirical }\end{array}$ & $\begin{array}{l}209 \text { responses from top-1000 Taiwanese } \\
\text { service firms }\end{array}$ \\
\hline $\begin{array}{l}\text { (Chesbrough \& Schwartz, } \\
\text { 2007) }\end{array}$ & Conceptual & $\begin{array}{l}\text { Illustrative cases from pharma, } \\
\text { high-tech, software, consumer products }\end{array}$ \\
\hline (Chesbrough, 2007) & Conceptual & $\begin{array}{l}\text { Illustrative cases from pharma, } \\
\text { high-tech, consumer products }\end{array}$ \\
\hline (Chu \& Chen, 2011) & $\begin{array}{l}\text { Qualitative } \\
\text { empirical }\end{array}$ & Case of chip design foundries in Taiwan \\
\hline (Davey et al., 2010) & $\begin{array}{l}\text { Qualitative } \\
\text { empirical }\end{array}$ & Four UK-based medical devices SMEs \\
\hline (Davey et al., 2011) & $\begin{array}{l}\text { Qualitative } \\
\text { empirical }\end{array}$ & Seven UK-based medical devices SMEs \\
\hline $\begin{array}{l}\text { (Gassmann, Enkel, et al., } \\
\text { 2010) }\end{array}$ & Conceptual & (Introduction to special issue) \\
\hline
\end{tabular}




\begin{tabular}{|c|c|c|}
\hline (Jagoda et al., 2012) & $\begin{array}{l}\text { Qualitative } \\
\text { empirical }\end{array}$ & $\begin{array}{l}\text { Single-case study: small } \\
\text { land-development company }\end{array}$ \\
\hline (Kakaletris et al., 2004) & Conceptual & (Research project report) \\
\hline (Luo \& Chang, 2011) & $\begin{array}{l}\text { Qualitative } \\
\text { empirical }\end{array}$ & $\begin{array}{l}\text { Single-case study: research institute and } \\
\text { high-tech firm }\end{array}$ \\
\hline (Purdy et al., 2012) & Conceptual & $\begin{array}{l}\text { Illustrative cases from high tech, } \\
\text { venture capital, e-business }\end{array}$ \\
\hline (Romero \& Molina, 2011) & Conceptual & $\begin{array}{l}\text { Literature review on value co-creation } \\
\text { and co-innovation }\end{array}$ \\
\hline $\begin{array}{l}\text { (Sandulli \& Chesbrough, } \\
\text { 2009a) }\end{array}$ & Conceptual & $\begin{array}{l}\text { Illustrative cases from pharma, } \\
\text { high-tech, software, consumer products, } \\
\text { gastronomy }\end{array}$ \\
\hline $\begin{array}{l}\text { (Sheets \& Crawford, } \\
\text { 2012) }\end{array}$ & Conceptual & Illustrative cases from higher education \\
\hline (Soloviev et al., 2010) & Conceptual & Illustrative cases from software \\
\hline (Vetter et al., 2008) & Conceptual & (Research project report) \\
\hline (Y. Wang \& Zhou, 2012) & Conceptual & $\begin{array}{l}\text { National innovation system of emerging } \\
\text { countries }\end{array}$ \\
\hline
\end{tabular}

\subsubsection{Search B: Google Scholar}

Search for "Open business model*" anywhere in the publication. Manual screening of excerpts and (subsequently) abstracts of the 515 results. Selected publications:

\begin{tabular}{lll}
\hline Paper & Research type & Research design / Data base \\
\hline (Alexy \& George, 2011) & $\begin{array}{l}\text { Quantitative } \\
\text { empirical }\end{array}$ & $\begin{array}{l}\text { 52 US-exchange listed firms; 77 } \\
\text { announcement events }\end{array}$ \\
$\begin{array}{l}\text { (Frankenberger, Weiblen, } \\
\text { Qualitative } \\
\text { (Holm et al., 2013) }\end{array}$ & $\begin{array}{l}\text { Cases of three solution providers } \\
\text { Qualitative } \\
\text { empirical } \\
\text { Conceptual }\end{array}$ & Cases of two Danish newspapers \\
(Wang et al., 2009) & $\begin{array}{l}\text { Literature review on open innovation, } \\
\text { business model, business model } \\
\text { innovation } \\
\text { Case of research consortium, } \\
\text { comprising six companies }\end{array}$ \\
(Smith et al., 2010) & $\begin{array}{l}\text { Qualitative } \\
\text { empirical } \\
\text { Conceptual }\end{array}$ & $\begin{array}{l}\text { Literature on value co-creation and } \\
\text { business models reviewed }\end{array}$ \\
\hline Storbacka et al., 2012) & & \\
\hline
\end{tabular}




\section{Biography}

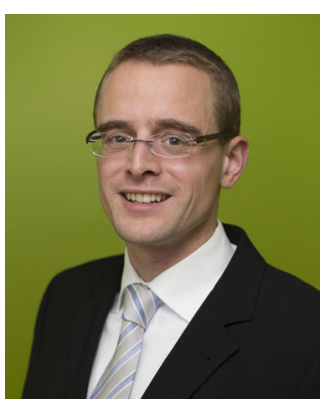

Tobias Weiblen is a $\mathrm{PhD}$ student and research associate at the Institute of Technology Management, University of St Gallen, Switzerland, and a visiting researcher at the Institute of Business Innovation, UC Berkeley, since Janury 2014. After obtaining his diploma in business administration from the University of Mannheim, Germany, in 2006 he worked as a business process consultant for SAP, supporting clients from different industries in supply chain optimization and supplier collaboration initiatives. His research interests include open and partner-based business models, as well as business model innovation. 